\title{
Isolation of Crude Oil from Polluted Waters Using Biosurfactants Pseudomonas Bacteria:
}

\author{
Assessment of Bacteria Concentration Effects
}

\author{
A. Khalifeh \\ Islamic Azad \\ University \\ Science and \\ Research \\ University \\ Tehran, Iran \\ anis.khalifeh@ \\ yahoo.com
}

\author{
B. Roozbehani \\ Research Center \\ of Petroleum \\ University of \\ Technology \\ Abadan, Iran \\ b.roozbehani@ \\ gmail.com
}

\author{
A. M. Moradi \\ Islamic Azad \\ University \\ Science and \\ Research \\ University \\ Tehran, Iran \\ dr.oil@gmail.com
}

\author{
S. Imani \\ Moqadam \\ Research Center \\ of Petroleum \\ University of \\ Technology \\ Abadan, Iran \\ saeedeh.imani@ \\ gmail.com
}

\author{
M. Mirdrikvand \\ Research Center \\ of Petroleum \\ University of \\ Technology \\ Abadan, Iran \\ mirdrikvand@ \\ gmail.com
}

\begin{abstract}
Biological decomposition techniques and isolation of environmental pollutions using biosurfactants bacteria are effective methods of environmental protection. Surfactants are amphiphilic compounds that are produced by local microorganisms and are able to reduce the surface and the stresses between surfaces. As a result, they will increase solubility, biological activity, and environmental decomposition of organic compounds. This study analyzes the effects of biosurfactants on crude oil recovery and its isolation using pseudomonas sea bacteria species. Preparation of biosurfactants was done in glass flasks and laboratory conditions. Experiments were carried out to obtain the best concentration of biosurfactants for isolating oil from water and destroying oil-inwater or water-in-oil emulsions in two $\mathrm{pH}$ ranges and four saline solutions of different concentrations. The most effective results were gained when a concentration of $0.1 \%$ biosurfactants was applied.
\end{abstract}

Keywords-environmental decomposition; biological separation; biosurfactant; pseudomonas; concentration.

\section{INTRODUCTION}

Studies over optimum methodologies for elimination of oil and refinery products from sea ecosystems are growing rapidly worldwide. Among applied physical and chemical methods, biological degradation is the most beneficial and economical one, in an environmental scope, for the elimination of oil pollutants [1]. Fortunately, a great amount of oil is degraded via sea microorganisms. The amount of these microorganisms is comprehensively greater in polluted areas. As a result, preparing suitable conditions can accelerate such activities for oil recovery and separation. The microorganisms suitable for biological degradation can be obtained from polluted areas or in the lab, with proper conditions [2].

Chromohalobacters, the bacteria that absorb oil pollutants, are advantageous since the released materials in their reactions are usually stable in salty solutions. Owing to the fact that most oil resources are located in salty areas, these biosurfactants are effective and efficient for oil elimination. Biosurfactants have always been applied in the revival and cleaning of polluted waters and hydrocarbons recovery. They can be applied as emulsioners, foam makers, moisturizers, and cleaners in the oil and petrochemical industry, environmental management systems and mining industries [3]. Chemical theories of biosurfactants have been applied to oil industry for oil recovery and more importantly for increasing the efficiency of the recovery process [4-5]. Biosurfactants attracted a great attention in environmental processes such as environmental cleaning of polluted waters and soil. Biosurfactants appeared in such processes as they have some effects such as dispersion, and environmental friendly factors naming low toxicity and biodegradability [6].

In this study, biosurfactants were produced from local bacteria and their influence on decreasing pollutants' concentration and their absorption from surroundings was analyzed. In addition, elimination of oil pollution from the area was accomplished as an environmental friendly method; it was done so that no oil residue remained after the cleaning. The oil was also recovered and used afterwards. This paper is going to analyze the effects of biosurfactants on biological degradation. The purpose of this study is to assess the influence of biosurfactants on environmental analysis of crude oil, using native bacteria separated from the Mahshahr exporting port, in pilot design and in laboratory conditions.

\section{MATERIALS AND METHODS}

\section{A. Sampling}

Samples were taken from Mahshahr exporting port located at Khur-Musa near the Persian Gulf in Khuzestan province, Iran. They were kept in a temperature near that of incubator until the bacteria were isolated. Salinity, $\mathrm{pH}$ and water 
temperature in the sample area were measured before and after sampling.

\section{B. Substances and bacterial culture}

The basic field of crude oil environmental analysis tests includes the materials that are illustrated in Table I along with their concentrations in the bacterial culture medium.

TABLE I. MATERIALS AND THEIR CONCENTRATION IN BACTERIAL CULTURE MEDIUM

\begin{tabular}{|c|c|}
\hline Material & Concentration \\
\hline $\mathrm{Na}_{2} \mathrm{HPO}_{4}$ & $2.2 \mathrm{gr} / \mathrm{lit}$ \\
\hline $\mathrm{KH}_{2} \mathrm{PO}_{4}$ & $1.4 \mathrm{gr} / \mathrm{lit}$ \\
\hline $\mathrm{MgSO}_{4} .7 \mathrm{H}_{2} \mathrm{O}$ & $0.6 \mathrm{gr} / \mathrm{lit}$ \\
\hline $\mathrm{FeSO}_{4} \cdot 7 \mathrm{H}_{2} \mathrm{O}$ & $0.02 \mathrm{gr} / \mathrm{lit}$ \\
\hline $\mathrm{NaCl}$ & $10.0 \mathrm{gr} / \mathrm{lit}$ \\
\hline $\mathrm{CaCl}_{2}$ & $0.08 \mathrm{gr} / \mathrm{lit}$ \\
\hline $\mathrm{Yeast}$ extract & $0.02 \mathrm{gr} / \mathrm{lit}$ \\
\hline $\mathrm{NaNO}_{3}$ & $1.0 \mathrm{gr} / \mathrm{lit}$ \\
\hline $\mathrm{Glucose}$ & $2 \% \mathrm{~V} / \mathrm{V}$ \\
\hline
\end{tabular}

Glucose was added to the culture plates as a carbohydrate source and $\mathrm{NaNO}_{3}$ and yeast extract as nitrogen sources. An amount of 1.5 milliliters of crude oil was eventually put through as the only hydrocarbon source. All experiments were carried out in $250 \mathrm{ml}$ flasks. A volume of 100 milliliters from base culture medium including $\% 2 \mathrm{v} / \mathrm{v}$ carbon hydrate source, $1 \mathrm{ml}$ of hydrocarbon source and $0.02 \mathrm{gr} / \mathrm{lit}$ of yeast extract was poured into Erlenmeyer flasks. An amount of $10^{5}$ to $10^{6}$ bacterial cells per each $\mathrm{ml}$ were inoculated into the Erlenmeyer flasks. Erlenmeyer flasks were left for a week in incubators of 120 revolutions per minute (rpm) rotation in a temperature of $32{ }^{\circ} \mathrm{C}$. Daily sampling was performed to define turbidity. Besides, $\mathrm{pH}$ variations were measured every day and adjusted to the initial value.

\section{DESIGNING THE EXPERIMENT IN LABORATORY SCALE}

In this part of the study, the experiment was designed and performed in laboratory scale in order to assess amount of oil absorption by biosurfactants. $\mathrm{pH}$ variations and salinity effects were analyzed.

\section{A. $p H$}

In order to measure $\mathrm{pH}$ variation effects on crude oil environmental degradation, an amount of $10^{5}$ to $10^{6}$ pseudomonas bacteria per milliliters were injected into two 250 $\mathrm{ml}$ Erlenmeyer flasks containing $100 \mathrm{ml}$ of base culture medium including hydrocarbon and carbohydrate nutrients. $\mathrm{pHs}$ of the mediums were adjusted on 8 and 8.5 respectively; the flasks were then kept in a temperature of $32{ }^{\circ} \mathrm{C}$ and rotation of $120 \mathrm{rpm}$ in the incubator. $\mathrm{pH}$ variations were recorded everyday and then adjusted to the set point. Figure 1 illustrates these variation effects.

\section{B. Salinity Effect}

Eight $250 \mathrm{ml}$ Erlenmeyer flasks, each containing $100 \mathrm{ml}$ of base bacterial culture medium, with salinities of $0.25 \%, 0.5 \%$, $1 \%$, and $2 \%$ were prepared. pHs of the solutions were adjusted to $8-8.5$; the test bacteria were then injected into the fields. Erlenmeyer flasks were kept in the incubator with a temperature of $32^{\circ} \mathrm{C}$ and rotation rate of $120 \mathrm{rpm}$ for a week. To assess the turbidity of solutions, sampling was done in 6 successive days. pHs were also recorded daily and then adjusted to the initial amount [6].

\section{ASSESSING THE RESUlTS}

\section{A. Bacteria cell growth and biosurfactant production}

The results of studies on pseudomonas bacterial cell growth represented crude oil consumptions as sources of carbon and energy. The results that were obtained after 5 days were similar to previous observations during production of these bacteria via these species [7]. The growth amount of most pseudomonas bacteria may be caused by more effective biodegradable features of pseudomonas compared to other species like bacillus. This fact comes after comparing nutrients; media culture situation and salinity in the other chemical cultivation studies [4]. Figure 2 illustrates cell growth analysis using turbidity assessment in different concentrations of salt.

\section{B. Analyzing diverse biosurfactant concentrations in crude oil segregation}

Bacterial culture medium in this research exhibits great amounts of cell growth and more separation activity with concentration of $0.1 \%$ of biosurfactant just like those of [6]. No considerable increase in separation activity occurred at higher concentrations. Biosurfactants were even identified in very low concentrations [8]. The maximum amount of bacterial degradation and oil separation species is $89 \%$ with a biosurfactant concentration of $0.1 \%$.

In this study, biosurfactants that were produced by these species in degradability test and oil segregation were used. Biosurfactant effect analysis was done in concentrations of $0.25 \%, 0.5 \%, 0.15 \%$, and $0.1 \%$ in various salinities. The best results was obtained in $0.1 \%$ concentration of biosurfactants, $\mathrm{pH}=8.5$ and salinity of $1.0 \%$. The results and comparisons are illustrated in Figure 3. The total pollution amount considered is $1000 \mathrm{ppm}$ and the figures show the results in proportion to the whole pollutions.

\section{Analysis of separation and oil degradability in laboratory scale}

Performing test stages in laboratory scale, in glass flasks, illustrated that maximum degradation and separation occurs when sources of phosphor and nitrogen are used in bacterial culture medium for biosurfactant production [9]. Analyzing all parameters declares that the presence of biosurfactants is the most important factor that destroys oil-in-water emulsion drops. 

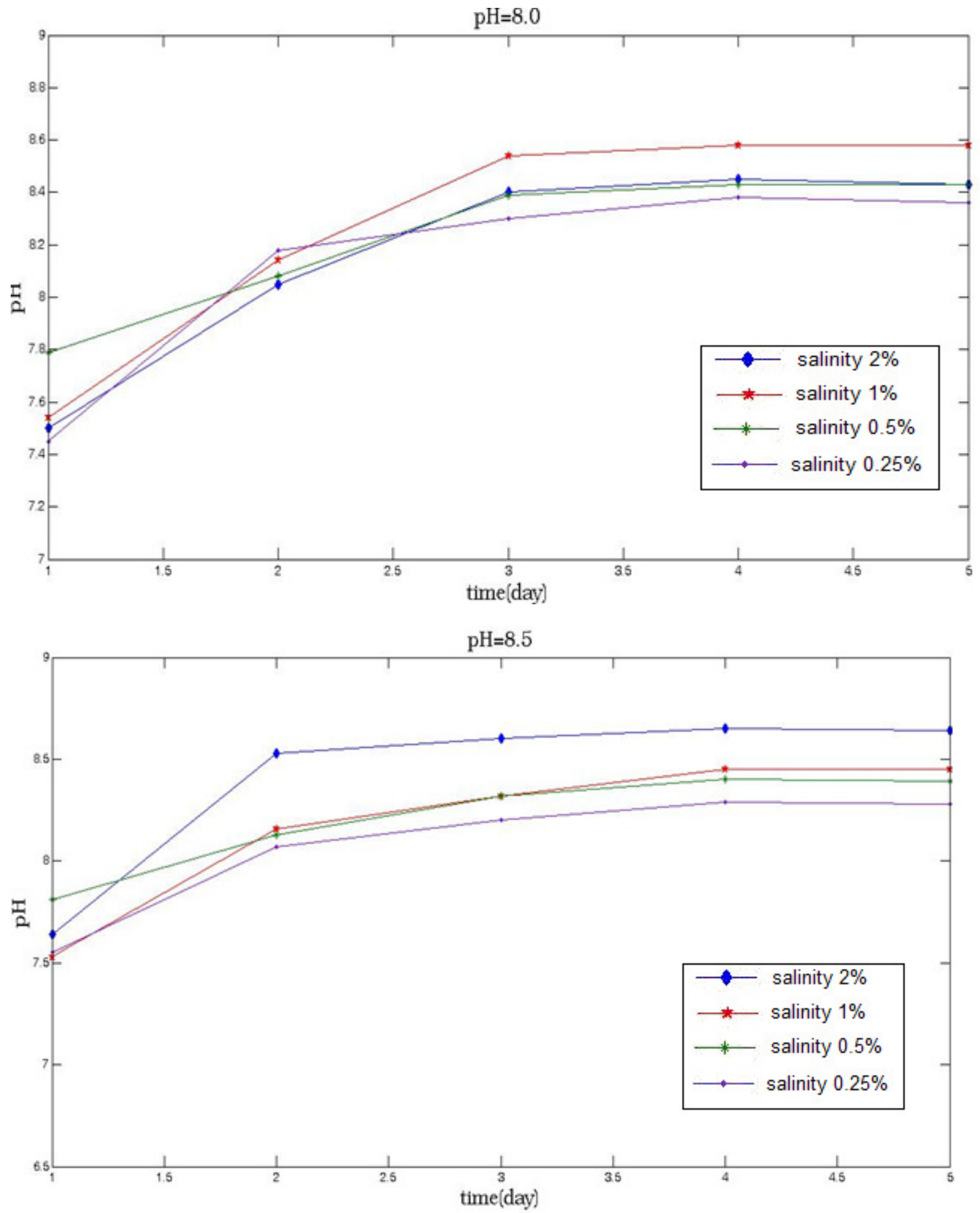

Fig. 1. Daily variations of $\mathrm{pH}$ in different salinities 

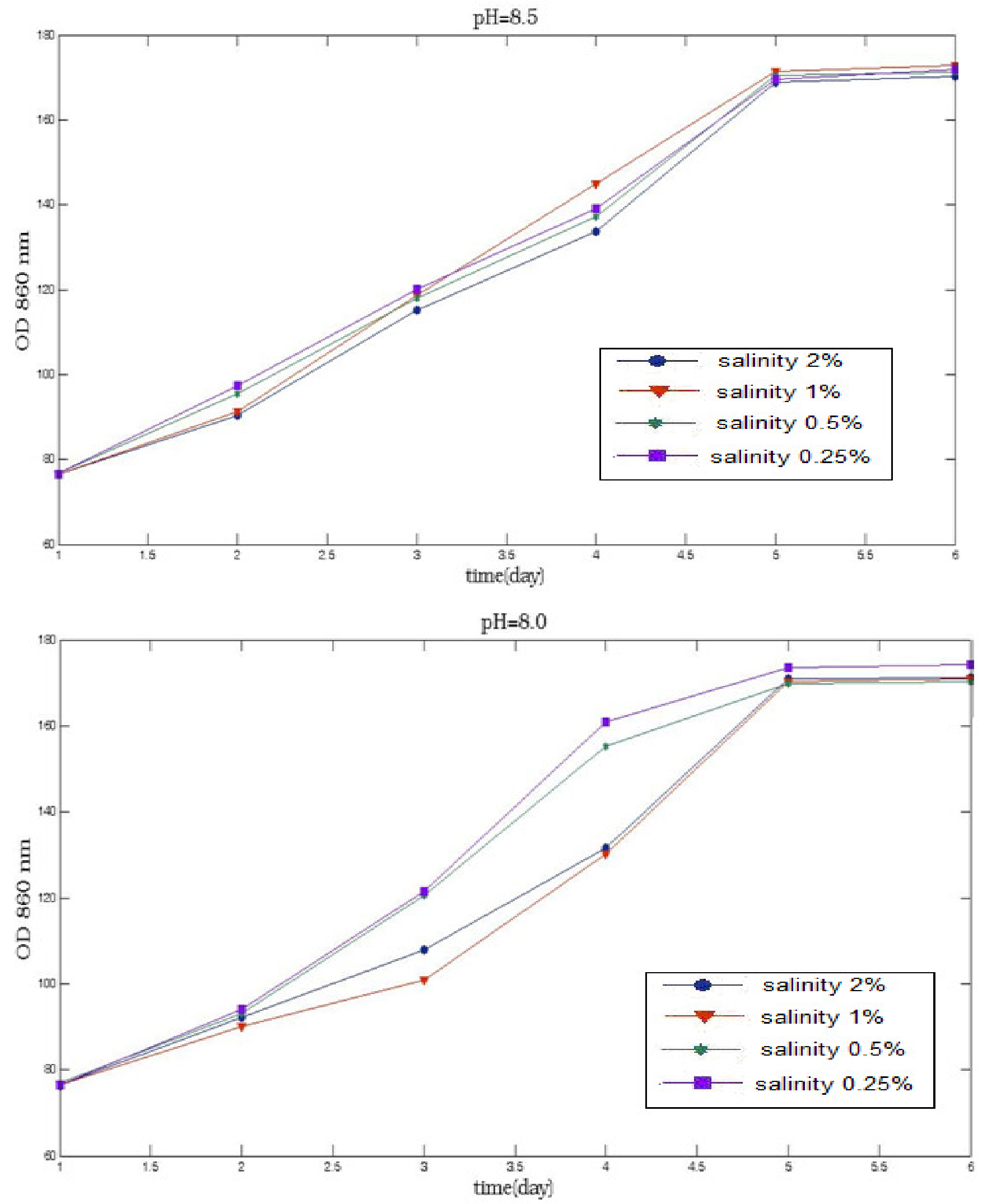

Fig. 2. Cell growth analysis using turbidity assessment in different concentrations of salt 

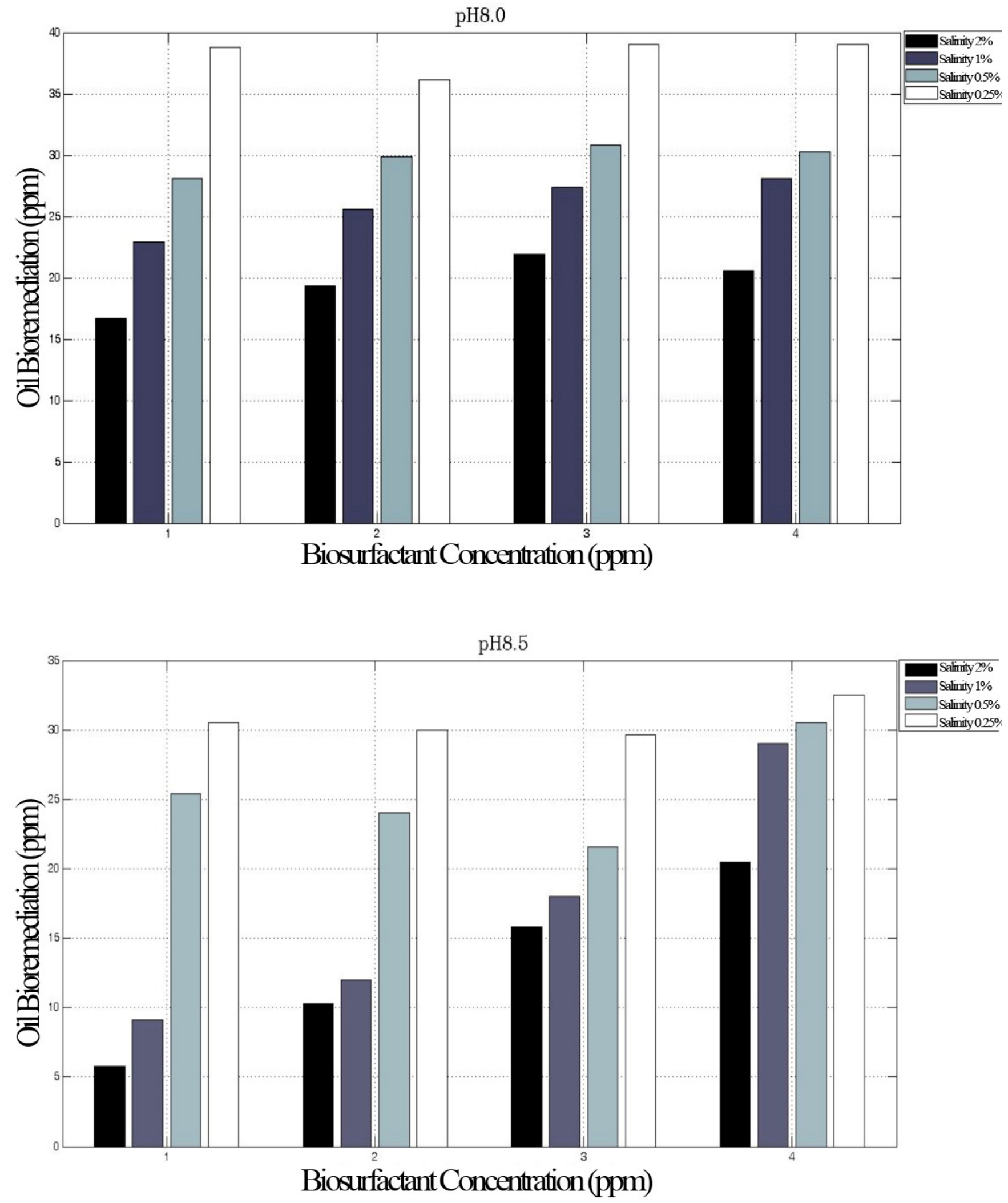

Fig. 3. The amount of residue oil in the area per total pollution amount (1000ppm) 


\section{IV. CONCLUSION}

Biosurfactants were applied to clean the polluted areas via the common strategy of being grown in bacterial culture plates and then added continuously to pollution sources. Application of biosurfactant in oil recovery is one of the most important methods of recovering a substantial amount of oil residue. Additions of biosurfactants increase degradation potential and oil segregation. Results illustrated that bacterial cell production via biosurfactants was much more effective than chemical surfactants. Biosurfactants were more advantageous due to their lower toxicity, native acceptance and biodegradability.

\section{ACKNOWLEDGMENT}

Special thanks to Abadan Refinery, Petroleum University of Technology and Imam Khomeini Hospital for their friendly non ending helps.

\section{REFERENCES}

[1] G. H. Ebrahimipur, J. Fuladi, A. Ferdosi, "Environmental factors' effect assessment on crude oil separation via extreme haluphil oil eater bacteria producing biosurfactant Pars Q2 and Gravimeter of oil cuts consumed by these bacteria in optimum conditions", Natural Science Journal, Vol. 13, pp. 59-70, 2005 (in Persian)

[2] G. H. Ebrahimipur, J. Fuladi, A. Ferdosi, "Separation and specification of RK extreme haluphil oil eater bacteria bearing biosurfactant and assessment of salt concentration amount on crude oil separation via this "suyeh"”, Natural Science Journal, Vol. 12, pp. 9-20, 2004 (in Persian)

[3] A. Singh, J. D. Van Hamme, O. P. Ward, "Surfactants in microbiology and biotechnology: Part 2. Application aspects", Biotechnology Advances, Vol. 25, No. 1, pp. 99-121, 2007

[4] M. P. Plociniczak, G. A. Plaza, Z. Piotrowska-Seget, S. S. Cameotra, "Environmental Application of Biosurfactants: Recent Advances", International Journal of Molecular Sciences, Vol. 12, No. 1, pp. 633654,2011

[5] N. K. Bordoloi, B. K. Onwar, "Microbial surfactant-enhanced mineral oil recovery under laboratory condition", Colloids and Surfaces, Vol. 63, No. 1, pp. 73-82, 2008

[6] R. Thavasi, S. Jayalakshmi, I. M. Banat, " Effect of biosurfactant and fertilizer on biodegradation of crude oil by marine isolates of Bacillus megaterium, Corynebacterium kutscheri and Pseudomonas aeruginosa", Bioresource Technology, Vol. 102, No. 2, pp. 772-778, 2011

[7] R. Thavasi, S. Jayalakshmi, T. Balasubramanian, I. M. Banat, "Production and characterization of a glycolipid biosurfactant from Bacillus megaterium using economically cheaper sources", World Journal of Microbiology and Biotechnology, Vol. 24, No. 7, pp. $917-$ 925, 2008

[8] Z. A. Raza, Z. M. Khalid, I. M. Banat, "Characterization of rhamnolipids produced by a Pseudomonas aeruginosa mutant strain grown on waste oils", Journal of Environmental Science and Health, Vol. 44, No. 13, pp. 1367-1373, 2009

[9] B. Kumari, S.N. Singh, D.P. Singh, "Characterization of two biosurfactant producing strains in crude oil degradation", Process Biochemistry, Vol. 47, No. 12, pp. 2463-2471, 2012 